\title{
Effect of Tempering Temperature on Microstructure and Mechanical Properties of Bainitic Railway Wheel Steel with Thermal Damage Resistance by Alloy Design
}

\author{
Jiaqi Zhu ${ }^{1}$, Zhunli Tan ${ }^{1, *}$, Yu Tian ${ }^{1}$, Bo Gao ${ }^{1}$, Min Zhang ${ }^{1}$, Junxiang Wang ${ }^{2}$ and Yuqing Weng ${ }^{1}$ \\ 1 School of Mechanical and Electronic Engineering, Beijing Jiaotong University, Beijing 100044, China; \\ 16116343@bjtu.edu.cn (J.Z.); 17121354@bjtu.edu.cn (Y.T.); 15121316@bjtu.edu.cn (B.G.); \\ zhangm@bjtu.edu.cn (M.Z.); weng@csm.org.cn (Y.W.) \\ 2 Technical Center, Tianjin Will Long Sci. \& Tech. Co., Ltd., Tianjin 300385, China; jxwtr@163.com \\ * Correspondence: tzli@bjtu.edu.cn; Tel.: +86-1381-167-8974
}

Received: 6 July 2020; Accepted: 28 August 2020; Published: 10 September 2020

\begin{abstract}
Thermal damage is one of the principle modes of wagon railway wheels. A new bainitic railway wheel steel with high thermal damage resistance and good combination of strength, plasticity, and toughness was developed. Microstructure and mechanical properties of the new steels in a tempered condition at different temperatures were examined. Microstructures were observed using scanning electron microscope and transmission electron microscope. Mechanical properties were evaluated by tensile, hardness, and Charpy impact tests with a simultaneous comparison to pearlitic railway wheel steel. The characteristic of retain austenite and $\mathrm{V}(\mathrm{C}, \mathrm{N})$ were measured through $\mathrm{X}$-ray diffractometry and energy disperse spectroscopy. The results indicate that this new bainitic wheel steel presents a submicron-sized carbide-free bainite morphology and preferable integrated mechanical properties when tempered at $280-360^{\circ} \mathrm{C}$. Precipitation strengthening plays an important role for the high strength, since a two-time-strengthening mechanism of the yield strength led by precipitation has been found at $280-360$ and $480-560^{\circ} \mathrm{C}$, respectively. Compared with a pearlitic railway wheel steel, bainitic wheel steel tempered at $320^{\circ} \mathrm{C}$ has a $10 \%$ higher yield strength, five times higher impact toughness, and much better thermal damage resistance, which is a promising railway wheel material for higher speed or heavier axle-load service conditions.
\end{abstract}

Keywords: bainite; railway wheel steel; tempering temperature; microstructure; mechanical properties; thermal damage resistance

\section{Introduction}

Wear, rolling contact fatigue ( $\mathrm{RCF}$ ), and thermal damage are principle failure modes of in-service railway wheels [1-3]. The present wheels mainly consist of ferrite and perlite microstructure. With the application of higher speed and heavier axle load, these failures happen more frequently and therefore, higher match of strength and toughness, better resistance to wear, RCF, and thermal damage is demanded for wheels to ensure safety and prolonged life [2,4]. Higher wear resistance is commonly achieved by improving strength. The present pearlitic wheel generally has a medium-high carbon content of $0.45-0.80 \mathrm{wt} . \%$ [5]. While it is noted that the lack of high toughness and relatively low austenitizing temperature make these kinds of steels vulnerable to thermal damage. Especially when railway wagon braking as well as transient high temperature in the contact zone between wheel and brake shoe can exceed the related austenitizing temperature, resulting in austenite formation in the wheel surface layer. Once the sliding stops, this local austenite rapidly cools down, forming a thin 
layer of brittle martensite. This untempered brittle martensite is likely to cause cracking under thermal stress and cycling load [6,7]. Therefore, a new series of railway wagon wheel steels which own both higher toughness and better thermal damage resistance has drawn much attention.

Bainitic steels, demonstrating an excellent match of higher strength and toughness, have been widely studied and utilized in many industrial fields including railway rails and crossings [8-14]. Therefore, related researches are trying to employ a bainitic microstructure as promising candidates for a new generation of railway wheels recently [15]. Sharma et al. tested a bainitic railway wheel steel made from MAS2 steel. This bainitic steel shows better wear resistance than the conventional pearlitic railway wheel steel [1]. Zhang et al. evaluated a kind of carbide-free bainitic (CFB) railway wheel steel with superior mechanical properties, especially high impact toughness. Related results show that it could be used for $30 \mathrm{t}$ axle-load wagon wheels [4,16,17]. Other researches indicate that higher yield strength and toughness of CFB can be obtained through tempering, although the tempering temperature corresponding to optimal properties depends on microstructures as well as the cooling process and sometimes is different from each other [18-21]. So far, the tempering temperature's effect on the microstructure and mechanical properties of CFB railway wheel steels has not been systematically investigated. Furthermore, its resistance to thermal damage has almost not been discussed. According to the forming mechanism of thermal cracks, improving the austenitizing temperature of wheel steel by alloy designing could be one effective method.

In this paper, a new CFB railway wheel steel with a high austenitizing temperature was developed by alloy design through simulation using the Thermo-Calc software. Samples in a similar shape and heat treatment process to the industrial wheel were fabricated. The effect of tempering temperature on the microstructure and mechanical properties were investigated systematically and the role of retained austenite (RA) and $\mathrm{V}(\mathrm{C}, \mathrm{N})$ in the tempering process were interpreted. Moreover, the improvement of thermal damage resistance was verified via the thermal fatigue test.

\section{Alloy Design}

The influence of alloy content on austenitizing temperature was calculated by the Thermo-Calc 2020 software (Thermo-Calc Software, Solna, Sweden). Based on our previous work, the basic chemical composition was set as $0.15 \mathrm{C}-1.8 \mathrm{Mn}-1.2 \mathrm{Si}-0.4 \mathrm{Cr}-0.3 \mathrm{Ni}$ (wt.\%). The phase content of face-centered cubic (FCC) and body-centered cubic (BCC) was shown in Figure 1. FCC's volume fraction and BCC's become 1 and 0 at the $A_{e}$ temperature, respectively. The $A_{e} 3$ temperature variation with contents of different elements was given in Figure 2. It is shown that there is a nearly linear relationship between the $A_{e}$ temperature variation and the increased content of each element. The $A_{e}$ temperature goes up with $\mathrm{Si}$ and $\mathrm{V}$ increment, but goes down with the improvement of $\mathrm{Mn}, \mathrm{Mo}$, Ni content. In these elements, $\mathrm{V}$ has the strongest effect pushing the $\mathrm{A}_{\mathrm{e} 3}$ temperature upward. Based on the principle of obtaining higher austenitizing temperature, the chemical compositions of the new railway wheel steel are given in Table 1.

The carbon content of a bainitic wheel steel is about $0.2 \mathrm{wt} \%$, which will greatly increase the $\mathrm{Ac}_{3}$ temperature compared to a traditional pearlitic wheel steel CL60 or CL70 with carbon content of 0.6 and 0.7 wt.\%, respectively. The strength loss by restricting carbon content can be offset by the addition of solution strengthening elements such as Si, Mn, and Mo [2]. Moreover, Mn and Mo addition will effectively enhance hardenability and promote bainitic transformation, leading to a desired microstructure and uniform hardness. Si plays an important role in carbide-free bainite steel, which can retard the formation of cementite during cooling and tempering, thus allowing austenite to retain between bainite ferrite laths and increasing the tempering resistance [22-26]. Except for the toughness enhancement effect, $\mathrm{Ni}$ addition can compensate the latent negative effect of relatively high amount of Si or Mn addition on toughness [23,27,28]. The objective of V addition is to refine bainite plate size and achieve precipitation strengthening by $\mathrm{V}(\mathrm{C}, \mathrm{N})$ precipitation, simultaneously to enhance the austenitizing temperature [29-31]. 


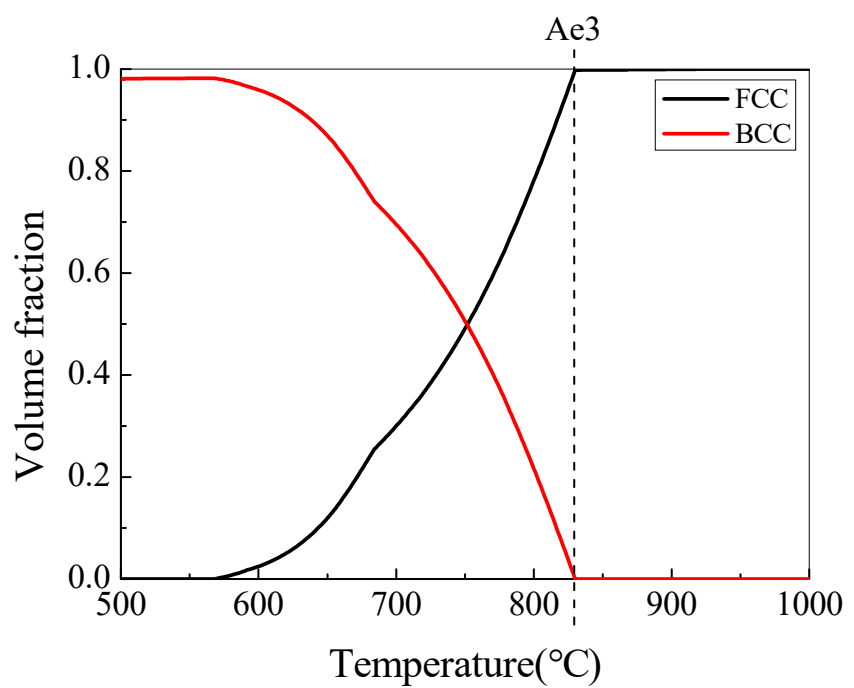

Figure 1. Volume fraction of body-centered cubic (BCC) and face-centered cubic (FCC) at different temperatures.

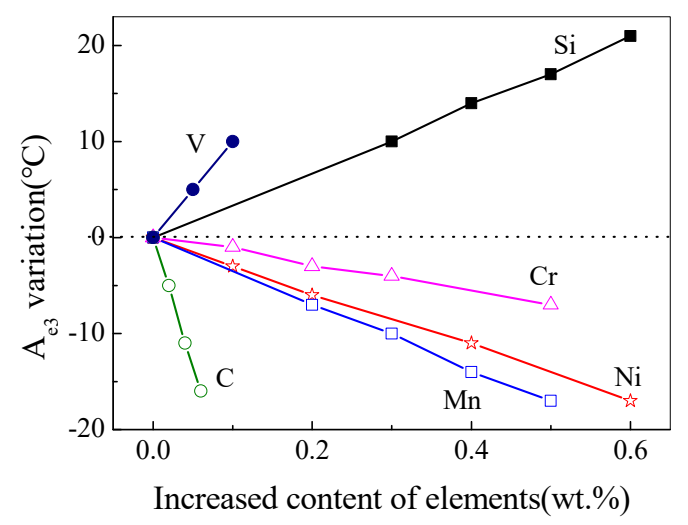

Figure 2. $\mathrm{A}_{\mathrm{e} 3}$ temperature varies with increased content of different elements.

Table 1. Chemical composition of experimental wheel steel wt.\%.

\begin{tabular}{lccccccc}
\hline $\mathbf{C}$ & $\mathbf{M n}$ & $\mathbf{S i}+\mathbf{M o}$ & $\mathbf{N i}$ & $\mathbf{V}$ & $\mathbf{P}$ & $\mathbf{S}$ & $\mathbf{F e}$ \\
\hline 0.22 & 2.2 & $1.5 \sim 2.2$ & 0.4 & 0.1 & 0.010 & 0.006 & Bal. \\
\hline
\end{tabular}

\section{Experimental}

\subsection{Treatment}

Tested samples were machined from a forged cylinder ingot with $840 \mathrm{~mm}$ diameter and $140 \mathrm{~mm}$ thickness, as shown in Figure 3. The continuous cooling transformation (CCT) diagram as well as the austenitizing temperature were measured using DIL805A thermodilatometry (TA Instruments, New Castle, DE, USA) with a sample of $\Phi 4 \mathrm{~mm} \times 10 \mathrm{~mm}$. Samples were heated at a rate of $10^{\circ} \mathrm{C} / \mathrm{s}$ to $930^{\circ} \mathrm{C}$ and then held for $10 \mathrm{~min}$, followed by cooling down to room temperature at a rate from 0.05 to $50{ }^{\circ} \mathrm{C} / \mathrm{s}$. The $\mathrm{A}_{\mathrm{c} 3}$ temperature of employed bainitic wheel steel is $881^{\circ} \mathrm{C}$, much higher than the traditional pearlitic wheel steel CL60.

All the samples treated by austenitization at $930{ }^{\circ} \mathrm{C}$ for $5 \mathrm{~h}$ were cooled by water spraying on the surface for $5 \mathrm{~min}$. After that, the samples were air cooled to room temperature and then tempered at 240-640 ${ }^{\circ} \mathrm{C}$ for $5 \mathrm{~h}$. 


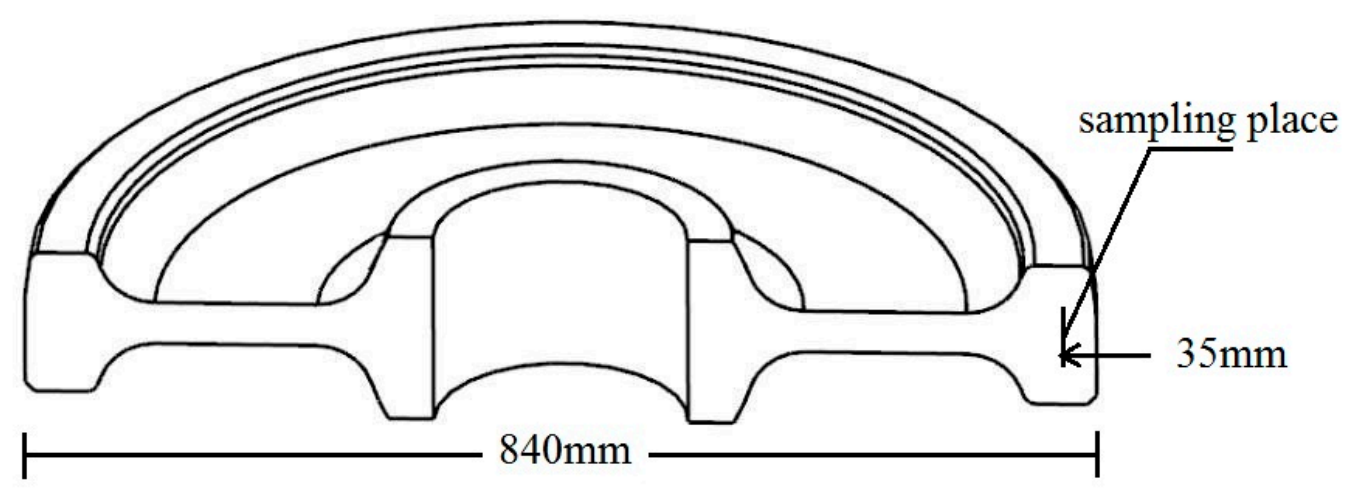

Figure 3. Structure of the forged cylinder ingot and the sampling place.

\subsection{Microstructure Characterization}

Samples used for microstructure observation and retained austenite (RA) analysis were obtained at the position in $35 \mathrm{~mm}$ depth from the top surface (Figure 3). The microstructure was observed by scanning electron microscope (SEM, Zeiss EVO18, $20 \mathrm{kV}$, Tokyo, Japan) and transmission electron microscope (TEM, FEI TECNAI G20, $200 \mathrm{kV}$, Tokyo, Japan). The precipitation was characterized using energy disperse spectroscopy (EDS). SEM specimens were polished and etched with a 3\% natal solution. TEM specimens were prepared using a twin-jet electropolishing instrument in $7 \%$ perchloric acid at around $-15{ }^{\circ} \mathrm{C}$. The volume fractions of retained austenite were measured by X-ray diffractometry (XRD, CuK $\alpha$ radiation, Rigaku, Tokyo, Japan) with a $2 \theta$ ranging from 35 to $95^{\circ}$ at a speed of $3^{\circ}$ per $\mathrm{min}$, and calculated through the direct comparison method through the integrated intensities of (200), (220), (311) peaks of austenite and those of (200) and (211) peaks of ferrite [15]. The carbon content $\chi_{C}$ of RA was calculated by the Nelson-Riley extrapolation method [32]:

$$
\alpha_{\gamma}=0.3556+0.00453 \chi_{C}
$$

where $\alpha_{\gamma}$ is the lattice parameter of austenite. The Ms of RA was estimated as [19]:

$$
\mathrm{Ms}=539-423 \chi_{\mathrm{C}}-30.4 \chi_{\mathrm{Mn}}-12.1 \chi_{\mathrm{Cr}}-7.5 \chi_{\mathrm{Si}}
$$

where $\chi_{\mathrm{Mn}}, \chi_{\mathrm{Cr}}$, and $\chi_{\mathrm{Si}}$ are the mass ratio of manganese, chromium, and silicon, respectively. The carbon content in the retained austenite is much higher than that in the prior austenite, so the corresponding Ms of RA is different from that of prior austenite.

\subsection{Mechanical Properties}

Samples for tensile and impact tests were gotten from a $35 \mathrm{~mm}$ depth position from the top surface. Tensile tests were executed on the universal testing machine using M12 standard specimens with a $1 \mathrm{~mm} / \mathrm{min}$ loading rate. Charpy U-notch impact toughness was tested using $10 \mathrm{~mm} \times 10 \mathrm{~mm} \times 55 \mathrm{~mm}$ specimens at the temperature from $-60{ }^{\circ} \mathrm{C}$ to room temperature $\left(20^{\circ} \mathrm{C}\right)$.

Mechanical properties of the CL70 wheel were tested as a contrast.

\subsection{Thermal Damage Resistance}

Samples used in thermal fatigue tests were taken from the experimental bainitic wheel steel and commercial pearlitic wheel CL70 and the dimension is shown in Figure 4. Samples were heated to $600^{\circ} \mathrm{C}$ and then cooled to room temperature by water cooling. This process was repeated 20 and 50 times, respectively. The morphology and distribution of thermal cracks were observed by an optical microscope $(\mathrm{OM})$ after derusting in a $10 \% \mathrm{HCl}$ solution and slight polishing of the sample surface. 


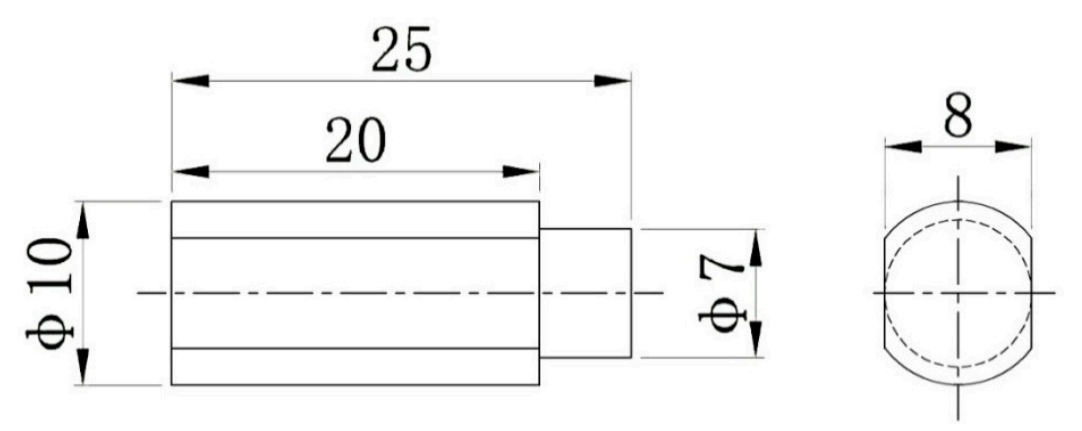

Figure 4. Dimension of samples for the thermal fatigue test (mm).

\section{Results and Discussion}

\subsection{Microstructure}

Figure 5 shows the CCT diagram of the experimental steel. Pearlite or proeutectoid ferrite will not form when the cooling rate is higher than $0.05^{\circ} \mathrm{C} / \mathrm{s}$. The microstructure at the ingot surface consists of bainite and martensite, where the fastest cooling rate exists. While inside the ingot with a slower cooling rate, the microstructure is mainly composed of bainite.

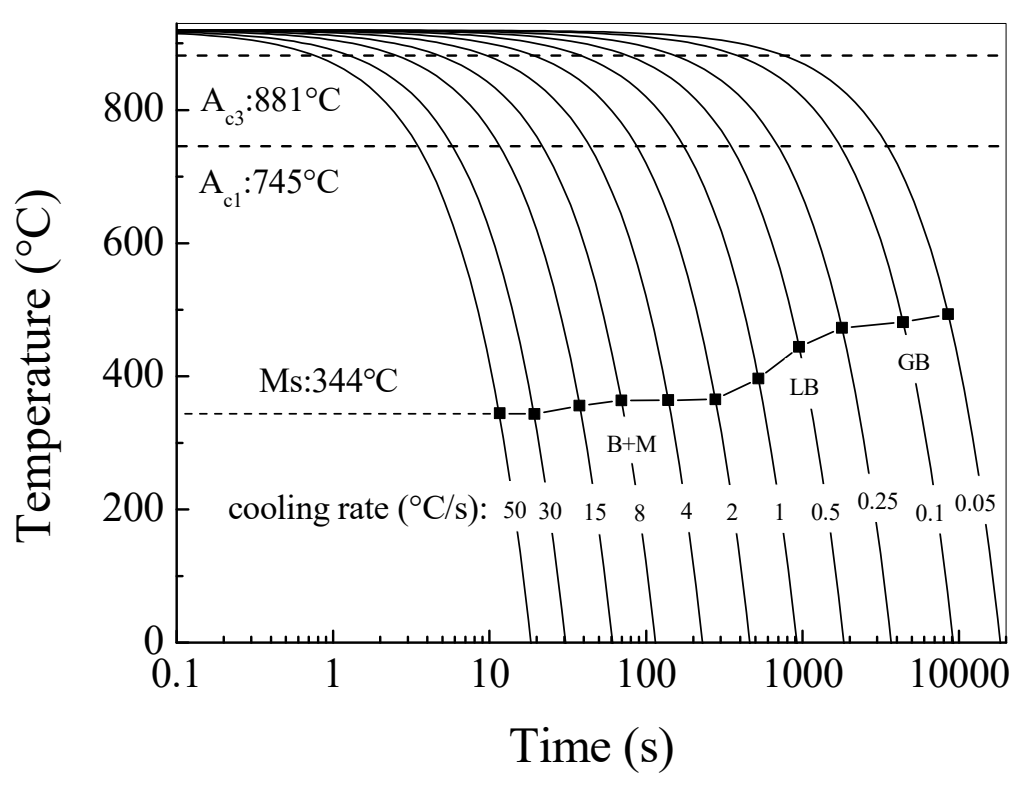

Figure 5. The continuous cooling transformation (CCT) diagram of employed steel.

Figure 6 shows a typical microstructure of specimens tempered at different temperatures. The morphologies at a $320^{\circ} \mathrm{C}$ tempered state is mainly carbide-free bainite. Fine lath-shaped bainite (LB) and granular bainite (GB) microstructures could be observed clearly (Figure 6a). When the tempering temperature was above $440^{\circ} \mathrm{C}$, the decomposition of RA became remarkable, and some of the bainite ferrite (BF) laths began to merge (Figure 6b). Once the tempering temperature was improved to $640^{\circ} \mathrm{C}$, RA almost completely dissolved and the recrystallization phenomenon could be observed, with plenty of precipitates distributed along the recrystallized grain boundaries (Figure 6c). 

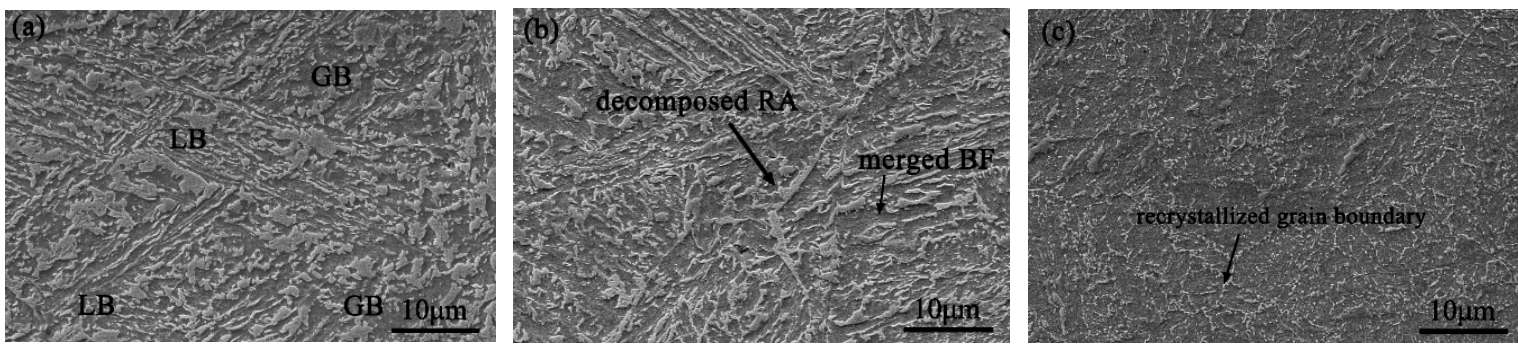

Figure 6. SEM microstructures of employed specimens tempered at different temperatures, (a) $320^{\circ} \mathrm{C}$, (b) $440{ }^{\circ} \mathrm{C}$, (c) $640{ }^{\circ} \mathrm{C}$.

TEM images of typical carbide-free bainite micrographs of $320^{\circ} \mathrm{C}$ tempered specimens are shown in Figure 7. Obviously, the submicron-sized filmy RA $(0.2 \mu \mathrm{m})$ was embedded within submicron-sized bainite ferrite laths $(0.5-1 \mu \mathrm{m})$ (Figure 7a). Si addition can improve the tempering resistance and promote thermal stability of RA. As a result, the filmy RA and blocky RA existed together after $320^{\circ} \mathrm{C}$ tempering in the size of less than $1 \mu \mathrm{m}$, as shown in Figure 7b,c. Fine BF laths and stabled filmy RA contribute to a high match of strength and toughness [15].

Figure 8 demonstrates the TEM micrograph and EDS analysis result of precipitates in the $480{ }^{\circ} \mathrm{C}$ tempered specimen. Much more particles are able to be easily observed, such as those pointed by arrows in Figure 8a. These fine and uniformly distributed particles exhibit an average size of 10-20 nm. The EDS results proved that these particles are $\mathrm{V}(\mathrm{C}, \mathrm{N})$ (Figure $8 \mathrm{~b}$ ). It is noted that these kinds of particles can hardly be recognized in the $320^{\circ} \mathrm{C}$-tempered specimen.
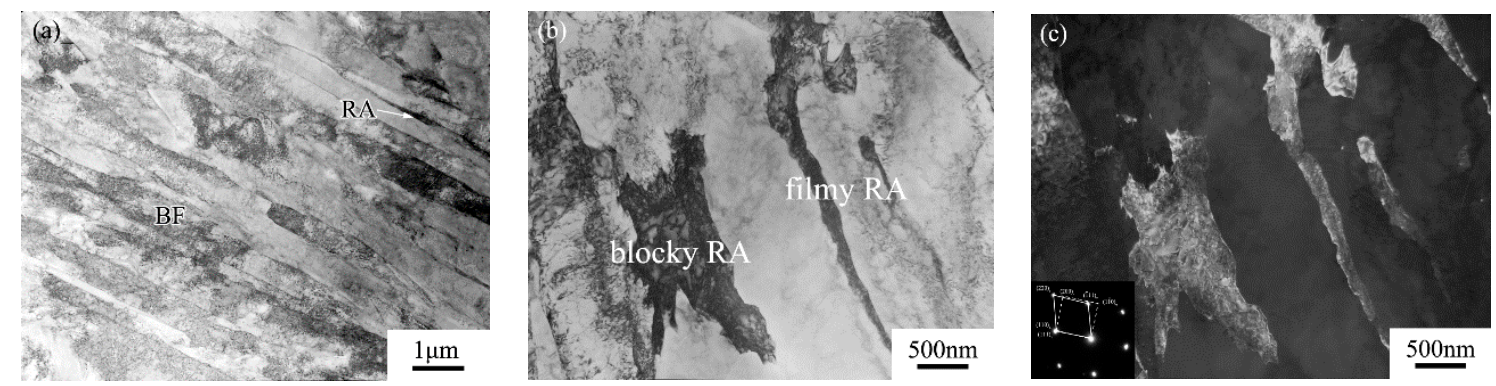

Figure 7. TEM images of microstructures for the $320^{\circ} \mathrm{C}$ tempered specimen. (a) carbide-free bainitic (CFB) lath, (b) bright field, and (c) dark field of film retained austenite (RA) and blocky RA.
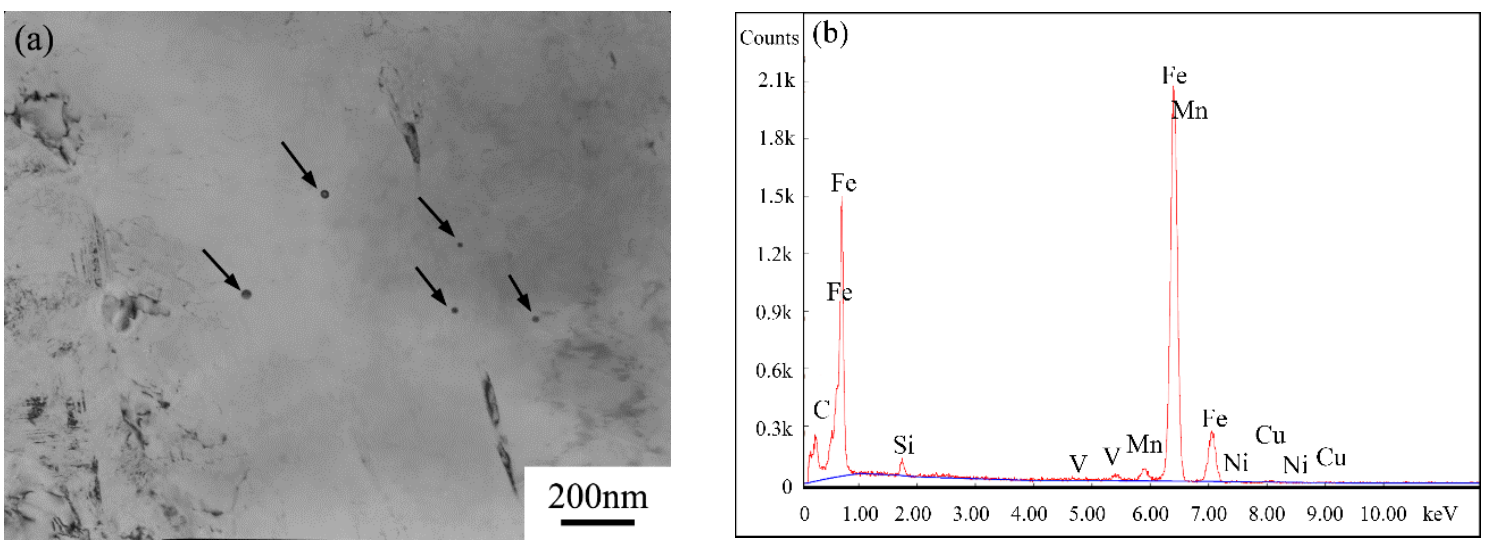

Figure 8. (a) TEM images and the (b) EDS results of precipitates in the $480{ }^{\circ} \mathrm{C}$ tempered specimens. 
The characteristic of retained austenite measured by XRD is listed in Table 2 . The retained austenite volume before tempering is $13.7 \%$, much higher than those in the tempered condition. This indicates that the tempering treatment is effective in RA's decomposition and transformation. The RA volume has no significant difference among the samples tempered from 240 to $400^{\circ} \mathrm{C}$, generally keeping within $6.5-8 \%$. However, once the tempering temperature is enhanced to $440{ }^{\circ} \mathrm{C}$, the corresponding RA content decreased sharply to about $2.5 \%$. The thermal stability of retained austenite is mainly determined by its carbon content, and the carbon content maintained about $1.3 \%$ between $240 \sim 360{ }^{\circ} \mathrm{C}$ tempering treatments. The corresponding calculated $\mathrm{Ms}$ is nearly $-80^{\circ} \mathrm{C}$. If the carbon content drops to $1 \%$ or even lower as the sample tempered at $440{ }^{\circ} \mathrm{C}$ or above, Ms will be under room temperature. This means that the unconverted retained austenite could also transform through the appropriate treatment.

In summary, the microstructure of designed wheel steel tempered at the temperature from 280 to $360{ }^{\circ} \mathrm{C}$ include a fine carbide-free bainite structure with $6.4 \sim 7.6 \%$ RA existing between bainite lath and inside GB. These RAs demonstrate an impressive thermal stability for their relatively high carbon content of 1.31 1.34\%. There is no observation of Inter-lath carbide, which could enhance the damage resistance of the steel [33].

Table 2. The characteristic of retained austenite of the tested wheel steel.

\begin{tabular}{cccc}
\hline $\begin{array}{c}\text { Tempering } \\
\text { Temperature/ }{ }^{\circ} \mathbf{C}\end{array}$ & $\begin{array}{c}\text { Volume of Retained } \\
\text { Austenite/\% }\end{array}$ & $\begin{array}{c}\text { Carbon content of } \\
\text { Retained Austenite/\% }\end{array}$ & $\begin{array}{c}\text { Ms of Retained } \\
\text { Austenite/ }{ }^{\circ} \mathbf{C}\end{array}$ \\
\hline $\begin{array}{c}\text { As-quenched } \\
240\end{array}$ & 13.7 & 1.06 & 20 \\
280 & 8.3 & 1.24 & -56 \\
320 & 6.6 & 1.34 & -99 \\
360 & 7.6 & 1.31 & -86 \\
400 & 6.4 & 1.31 & -86 \\
440 & 7.7 & 1.16 & -23 \\
\end{tabular}

\subsection{Mechanical Properties}

Mechanical properties of the samples at different tempering temperatures are shown in Table 3. Tensile strength, yield strength, hardness, and plasticity basically maintained a high level between tempering temperature of 240 to $560{ }^{\circ} \mathrm{C}$. The tensile strength was about $1050 \mathrm{MPa}$, the hardness has a similar tendency, keeping within 33 to $35 \mathrm{HRC}$. While the yield strength demonstrated two peaks, at $\sim 360$ and $\sim 560{ }^{\circ} \mathrm{C}$, indicating that there existed a two-time-strengthening mechanism with the tempering temperature increment. The primary strengthening stage should be attributed to cementite precipitation, at about $360^{\circ} \mathrm{C}$ which was not high enough for $\mathrm{V}(\mathrm{C}, \mathrm{N})$ to precipitate. When the tempering temperature improved to $480^{\circ} \mathrm{C}$, fine $\mathrm{V}(\mathrm{C}, \mathrm{N})$ could precipitate largely, and the steel's yield strength got $39 \mathrm{MPa}$ enhancement compared with that tempered at $440{ }^{\circ} \mathrm{C}$. The strengthening contribution of $\mathrm{V}(\mathrm{C}, \mathrm{N})$ can be shown by the Ashby-Orowan equation as follows [34]:

$$
\sigma_{\mathrm{p}}=\frac{5.9 \sqrt{f}}{\bar{x}} \ln \left[\frac{\bar{x}}{2.5 \times 10^{-4}}\right]
$$

where $\sigma_{\mathrm{p}}$ represents precipitation strengthening $(\mathrm{MPa}), f$ is the volume fraction of precipitates and $\bar{x}$ is the average precipitation size $(\mu \mathrm{m})$. Here, $f$ and $\bar{x}$ values at $480{ }^{\circ} \mathrm{C}$ tempered state can be obtained from Figure 7a. The corresponding calculated $\sigma_{\mathrm{p}}$ value is $40 \mathrm{MPa}$, which is close to the testing result. This indicates that $\mathrm{V}(\mathrm{C}, \mathrm{N})$ precipitation is the main driving force of secondary strengthening stage, and this effect reached a maximum extent at $\sim 560{ }^{\circ} \mathrm{C}$. The elongation increased from $18 \%$ to $20 \%$ when the tempering temperature changed from 240 to $400{ }^{\circ} \mathrm{C}$, while then fell down to $17 \%$ at 440 and $480^{\circ} \mathrm{C}$. Notably, when the tempering temperature was up to over $560{ }^{\circ} \mathrm{C}$, both tensile strength and yield strength declined obviously and meanwhile, the plasticity and toughness recovered as a 
consequence of recrystallization. Therefore, this designed steel shows an excellent match of strength and plasticity when the tempering temperature is below $560^{\circ} \mathrm{C}$.

Table 3. Mechanical properties of the tested wheel steel.

\begin{tabular}{cccccc}
\hline $\begin{array}{c}\text { Tempering } \\
\text { Temperature/ }\end{array}$ & $\begin{array}{c}\text { Tensile } \\
\text { Strength/MPa }\end{array}$ & $\begin{array}{c}\text { Yield } \\
\text { Strength/Mpa }\end{array}$ & $\begin{array}{c}\text { Elongation to } \\
\text { fracture/\% }\end{array}$ & $\begin{array}{c}\text { Hardness } \\
\text { HRC }\end{array}$ & $\begin{array}{c}\text { Impact } \\
\text { Energy/J }\end{array}$ \\
\hline 240 & 1072 & 794 & 18.5 & 34 & 138 \\
280 & 1050 & 814 & 18 & 32 & 170 \\
320 & 1055 & 837 & 19 & 33 & 157 \\
360 & 1051 & 843 & 19 & 35 & 144 \\
400 & 1054 & 827 & 20 & 34 & 88 \\
440 & 1090 & 754 & 17 & 33 & 59 \\
480 & 1075 & 793 & 17 & 34 & 51 \\
560 & 1047 & 858 & 19 & 33 & 53 \\
640 & 921 & 786 & 21 & 28 & 80 \\
\hline
\end{tabular}

As shown in Table 3, samples tempered at $240-360{ }^{\circ} \mathrm{C}$ exhibited excellent impact properties and reached a peak impact energy value of $170 \mathrm{~J}$ at $280^{\circ} \mathrm{C}$. High impact energy is related to film retained austenite existence, which played an important role in blocking crack propagation. However, when temperature was higher than $400^{\circ} \mathrm{C}$, the impact energy decreased rapidly, appearing obvious brittlement tendency. The valley value appeared at about $480{ }^{\circ} \mathrm{C}$. This steel shows only one style of temper brittleness from 400 to $560{ }^{\circ} \mathrm{C}$, different from the traditional two steps shown in common steels. Si bearing is the main reason for this phenomenon, which enhanced the temper resistance by suppressing the grain-boundary precipitation of cementite and thus retarded the appearance of first tempering brittleness.

From Figure 9, the tempering temperature's effect on impact energy was similar to that on the carbon content in retained austenite. An approximately linear relationship between toughness and carbon content in RA was revealed in Figure $9 \mathrm{~b}$ and the equation is as follows:

$$
\mathrm{Ak}_{\mathrm{u} 2}=357 \chi_{\mathrm{C}}-314
$$

where $\mathrm{Ak}_{\mathrm{u} 2}$ is the impact energy with a $\mathrm{U} 2$ notch and $\chi_{\mathrm{C}}$ is the carbon content of RA.

Here, the toughness of CFB steel strongly depends on the stability of retained austenite, while this stability is determined by its carbon content. Since the unstable RA may transform into a brittle martensite, which has a negative effect on toughness, on the contrary, the stable RA with high carbon content inside is good to better impact energy. As a consequence, it is an effective way of controlling the carbon content of RA for desirable impact energy to choose the appropriate tempering process.
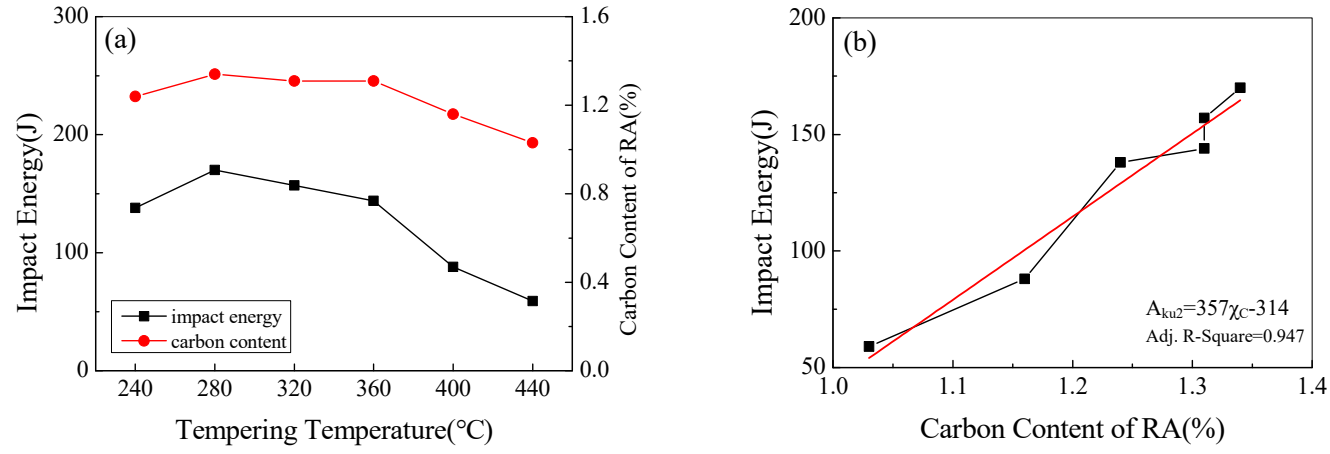

Figure 9. (a) The value and (b) the relationship of the impact energy and the carbon content of RA. 
The mechanical properties comparison between designed bainitic railway wheel steel here and pearlitic CL70 is shown in Table 4. This new steel has a better match of strength and toughness, demonstrating a much higher yield strength and impact toughness, as well as better plasticity.

Table 4. Mechanical properties comparison of $320{ }^{\circ} \mathrm{C}$ tempered tested bainitic wheel steels and a commercial pearlitic railway wheel steel.

\begin{tabular}{cccccc}
\hline $\begin{array}{c}\text { Microstructure } \\
\text { Pattern of } \\
\text { Wheel Steel }\end{array}$ & $\begin{array}{c}\text { Tensile } \\
\text { Strength/MPa }\end{array}$ & $\begin{array}{c}\text { Yield } \\
\text { Strength/Mpa }\end{array}$ & $\begin{array}{c}\text { Elongation to } \\
\text { Fracture/\% }\end{array}$ & Hardness HRC & $\begin{array}{c}\text { Impact } \\
\text { Energy/J }\end{array}$ \\
\hline CFB & 1055 & 837 & 19 & 33 & 157 \\
Pearlitic (CL70) & 1190 & 761 & 16 & 28 & 26 \\
\hline
\end{tabular}

Figure 10 shows the low temperature impact energy of the sample tempered at $320{ }^{\circ} \mathrm{C}$. The impact energy decreased continuously with the test temperature. Not like a typical curve, no ductile-brittle-transition phenomenon was observed from the curve in Figure 10. The impact energy was higher than $50 \mathrm{~J}$ even at $-60^{\circ} \mathrm{C}$, and samples presented excellent low temperature toughness. It has been reported that DBTT tends to increase with the increasing GB volume fraction and its grain size [35]. Therefore, improved hardenability and submicron-size structure of this designed wheel steel may be the primary cause of its higher low-temperature properties.

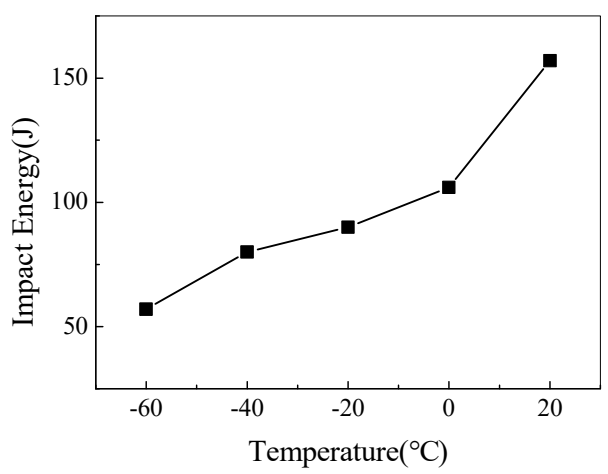

Figure 10. Low temperature impact energy of $320^{\circ} \mathrm{C}$-tempered wheel steel.

The tempering temperature has a great effect on microstructure and mechanical properties. Commonly, a desirable combination of strength and toughness should be achieved by adopting specific tempering temperatures according to different demands. However, a high match of strength and toughness can also be obtained through a board range of tempering temperature with proper alloy and microstructure design, as described in the article. For railway wheels in service, the crack is fatal to the safety. Therefore, toughness and RCF resistance become the most important properties. Therefore, to ensure a high toughness of the steel, the tempering temperature must be controlled to avoid temper brittleness which starts with $400{ }^{\circ} \mathrm{C}$. Moreover, the tempering temperature should be higher than $320^{\circ} \mathrm{C}$ to obtain a higher yield strength and plasticity. Relatively high tempering temperature may be helpful to wear resistance as well, relying on more second-phase particles precipitated.

TEM results indicate that substantial precipitation of $\mathrm{V}(\mathrm{C}, \mathrm{N})$ requires the tempering temperature higher than $480^{\circ} \mathrm{C}$. Within the proper tempering temperature range of railway wheel, precipitation strengthening has not been fully utilized. Even so, $\mathrm{V}$ is still helpful on lifting the $\mathrm{A}_{\mathrm{e} 3}$ temperature and the enhancement of overall properties with even a relatively low content.

\subsection{Thermal Damage Resistance}

Figure 11 shows OM examinations of samples after thermal fatigue tests. From Figure 11a,b, uniformly distributed microcracks with a consistent propagating direction were found in both pearlitic 
and bainitic wheel steels after 20 times cycling. However, the cracks of pearlitic wheel were much more and denser. When the thermal fatigue cycles increased to 50 times, cracks in pearlitic wheel propagated along the length direction and merged into wide cracks. A severe crack coalescence pearlitic wheel can be seen obviously in Figure 11c. While the cracks in bainitic wheel steel only increased in number and propagated limitedly as shown in Figure 11d, no widening was similar to that in pearlitic wheel. This indicates that the thermal damage resistance of the new designed bainitic wheel steel is better than pearlitic wheel. Recycled heating and cooling will cause repeated plastic deformation, leading to initiation propagation of fatigue cracks [36]. The pearlite microstructure consists of a soft ferrite phase and hard cementite phase and cracks are likely to initiate from ferrite whose plastic deformation is restricted by the surrounding cementite [37]. However, in the carbide-free bainite microstructure, the filmy RA in bainitic wheel can prevent cracks from initiation and propagation due to its prominent compatible deformation capability to some extent [38]. Therefore, the crack number in bainitic wheel is less than that in the pearlitic wheel after 20 times cycling and only developed in number but not so extremely merged as in pearlitic wheel even up to 50 times of thermal cycle.

Figure 12 shows the microstructure of bainitic sample after 20 and 50 times thermal cycles. It can be seen that there is no evident change on the microstructure of LB and GB except slight merging of bainite laths during thermal fatigue. This indicates that the employed bainitic steel has a high microstructure stability during thermal fatigue.
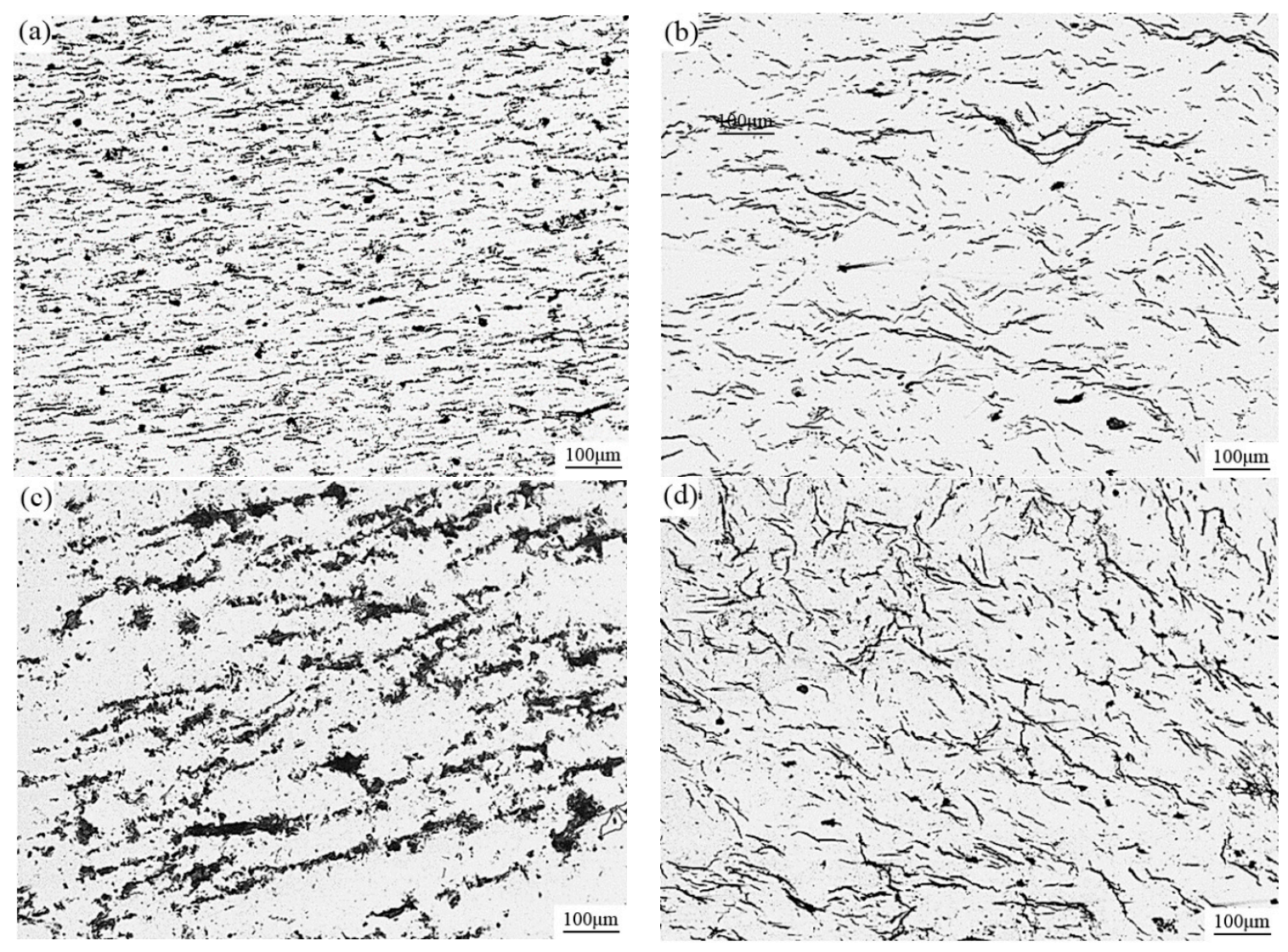

Figure 11. OM examinations of $(\mathbf{a}, \mathbf{c})$ pearlitic wheel and $(\mathbf{b}, \mathbf{d})$ bainitic wheel steel after $(\mathbf{a}, \mathbf{b}) 20$ times and $(\mathbf{c}, \mathbf{d}) 50$ times thermal cycles. 

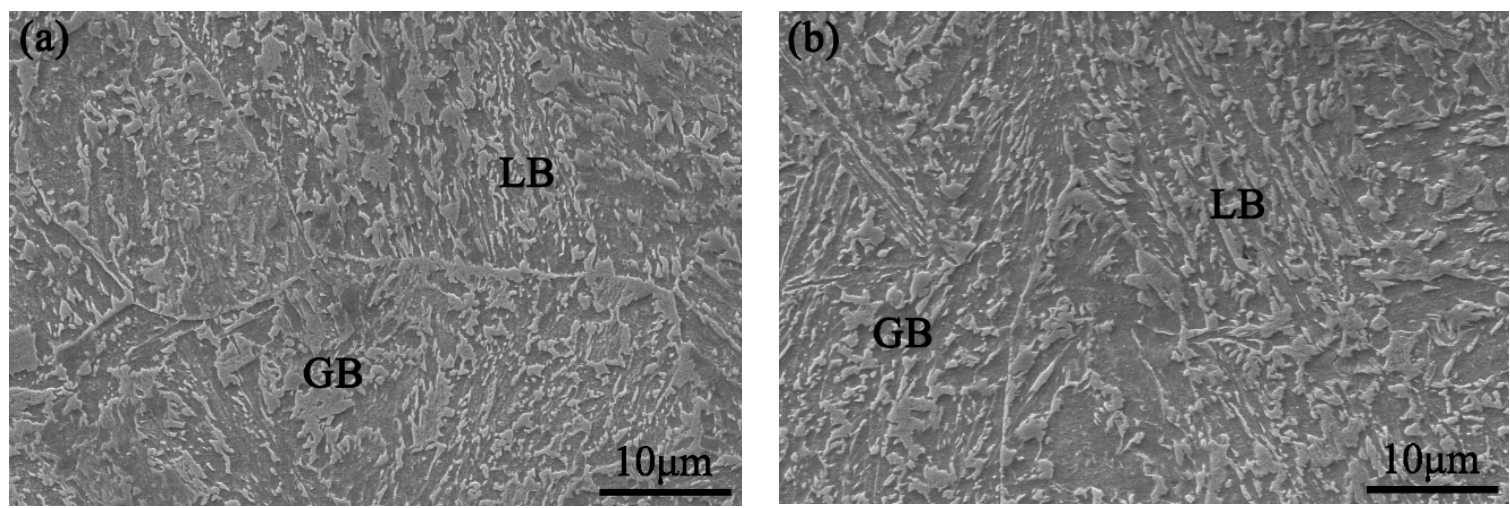

Figure 12. SEM images of bainitic wheel steel after (a) 20 times and (b) 50 times thermal cycles.

\section{Conclusions}

A new carbide-free bainitic wheel steel with $V$ addition was developed. The effect of tempering temperature on the microstructure and mechanical properties of this new developed wheel steel were studied. The conclusions were drawn as follows:

1. The new bainitic wheel steel achieved excellent integrated mechanical properties at the tempering temperature range of $280-360{ }^{\circ} \mathrm{C}$.

2. The tested steel has a two-time-strengthening mechanism of yield strength at $280-360{ }^{\circ} \mathrm{C}$ and $480-560{ }^{\circ} \mathrm{C}$, respectively. The latter one is led by fine $\mathrm{V}(\mathrm{C}, \mathrm{N})$ precipitation.

3. This new bainitic wheel steel shows a much higher match of strength and toughness at a proper tempered state than commercial pearlitic railway wheel steel Cl70, especially more excellent low temperature toughness.

4. The $\mathrm{V}$ bearing bainitic wheel steel has better thermal damage resistance than the commercial pearlitic wheel.

Author Contributions: Conceptualization, Z.T. and Y.W.; methodology, J.Z.; validation, Z.T., M.Z. and Y.W.; formal analysis, J.Z.; investigation, B.G.; resources, J.W.; data curation, J.Z.; data writing-original draft preparation, J.Z. and Y.T.; writing — review and editing, J.Z.; visualization, J.Z.; supervision, Y.T.; funding acquisition, Z.T. All authors have read and agreed to the published version of the manuscript.

Funding: This work was supported by the Fundamental Research Funds for the Central Universities, grant number 2019JBM103.

Conflicts of Interest: The authors declare no conflict of interest.

\section{References}

1. Sharma, S.; Sangal, S.; Mondal, K. Wear behavior of newly developed bainitic wheel steels. J. Mater. Eng. Perform. 2014, 24, 999-1010. [CrossRef]

2. Zeng, D.; Lu, L.; Gong, Y.; Zhang, N.; Gong, Y. Optimization of strength and toughness of railway wheel steel by alloy design. Mater. Des. 2016, 92, 998-1006. [CrossRef]

3. Su, H.; Pan, T.; Li, L.; Yang, C.F.; Cui, Y.H.; Ji, H.Z. Frictional heat-induced phase transformation on train wheel surface. J. Iron Steel Res. Int. 2008, 15, 49-55. [CrossRef]

4. Zhang, M.R.; Gu, H.C. Microstructure and properties of carbide free bainite railway wheels produced by programmed quenching. Mater. Sci. Technol. 2013, 23, 970-974. [CrossRef]

5. Kapito, A.; Stumpf, W.; Papo, M.J. On the development of bainitic alloys for railway wheel applications. J. S. Afr. Inst. Min. Met. 2012, 112, 539-544.

6. Ahlström, J.; Karlsson, B. Modelling of heat conduction and phase transformations during sliding of railway wheels. Wear 2002, 253, 291-300. [CrossRef]

7. Huai zhong, J.I.; Hang, S.U.; Yang, C.F.; Zhang, Y.Q. Friction heat induced phase transformation and spalling mechanism of train wheel steel. J. Iron Steel Res. 2005, 17, 55-59. 
8. Long, X.Y.; Kang, J.; Lv, B.; Zhang, F.C. Carbide-free bainite in medium carbon steel. Mater. Des. 2014, 64, 237-245. [CrossRef]

9. Leiro, A.; Roshan, A.; Sundin, K.G.; Vuorinen, E.; Prakash, B. Fatigue of 0.55C-1.72Si steel with tempered martensitic and carbide-free bainitic microstructures. Acta Metall. Sin. Engl. Lett. 2014, 27, 55-62. [CrossRef]

10. Graux, A.; Cazottes, S.; Castro, D.D.; San-Martín, D.; Capdevila, C.; Cabrera, J.M.; Molas, S.; Schreiber, S.; Mirković, D.; Danoix, F.; et al. Design and development of complex phase steels with improved combination of strength and stretch-flangeability. Metals 2020, 10, 824. [CrossRef]

11. Podgornik, B.; Brunčko, M.; Kirbiš, P. Wear resistance of high c high si steel with low retained austenite content and kinetically activated bainite. Metals 2020, 10, 672. [CrossRef]

12. Pushkareva, I.; Shalchi-Amirkhiz, B.; Allain, S.Y.P.; Geandier, G.; Fazeli, F.; Sztanko, M.; Scott, C. The influence of vanadium additions on isothermally formed bainite microstructures in medium carbon steels containing retained austenite. Metals 2020, 10, 392. [CrossRef]

13. Santacruz-Londoño, A.F.; Rios-Diez, O.; Jiménez, J.A.; Garcia-Mateo, C.; Aristizábal-Sierra, R. Microstructural and mechanical characterization of a nanostructured bainitic cast steel. Metals 2020, 10, 612. [CrossRef]

14. Tian, Y.; Tan, Z.L.; Li, J.; Gao, B.; Zhang, M.; Bai, B.Z. Low temperature deformation induced microstructure refinement and consequent ultrahigh toughness of a 20Mn2SiCrNi bainitic steel. Metals 2020, 10, 19. [CrossRef]

15. Wang, K.; Tan, Z.; Gao, G.; Gui, X.; Misra, R.D.; Bai, B. Ultrahigh strength-toughness combination in bainitic rail steel: The determining role of austenite stability during tempering. Mater. Sci. Eng. A 2016, 662, 162-168. [CrossRef]

16. Zhang, M.; Qian, J.; Gu, H. The structure stability of carbide-free bainite wheel steel. J. Mater. Eng. Perform. 2007, 16, 635-639. [CrossRef]

17. Zhang, M.R.; Gu, H.C. Fracture toughness of nanostructured railway wheels. Eng. Fract. Mech. 2008, 75, 5113-5121. [CrossRef]

18. Liu, D.; Bai, B.; Fang, H.; Zhang, W.; Gu, J.; Chang, K. Effect of tempering temperature and carbide free bainite on the mechanical characteristics of a high strength low alloy steel. Mater. Sci. Eng. A 2004, 371, 40-44. [CrossRef]

19. Guo, A.; Song, X.; Tang, J.; Yuan, Z. Effect of tempering temperature on the mechanical properties and microstructure of an copper-bearing low carbon bainitic steel. J. Univ. Sci. Technol. Beijing 2008, 15, 38-42. [CrossRef]

20. Yi, L.; Peng, J.M.; Wang, H.B.; Wu, X.C. Effect of tempering on microstructure and mechanical properties of a non-quenched bainitic steel. Mater. Sci. Eng. A 2010, 527, 3433-3437.

21. Kang, J.; Zhang, F.C.; Yang, X.W.; Lv, B.; Wu, K.M. Effect of tempering on the microstructure and mechanical properties of a medium carbon bainitic steel. Mater. Sci. Eng. A 2017, 686, 150-159. [CrossRef]

22. De Cooman, B.C. Structure-properties relationship in trip steels containing carbide-free bainite. Curr. Opin. Solid State Mater. Sci. 2004, 8, 285-303. [CrossRef]

23. Mesquita, R.A.; Kestenbach, H.J. On the effect of silicon on toughness in recent high quality hot work steels. Mater. Sci. Eng. A 2011, 528, 4856-4859. [CrossRef]

24. Qiu, J.A.; Wu, K.M.; Li, J.H.; Hodgson, P.D.; Hou, T.P.; Ding, Q.F. Effect of silicon on ultra-low temperature toughness of nb-ti microalloyed cryogenic pressure vessel steels. Mater. Charact. 2013, 83, 123-128. [CrossRef]

25. Kozeschnik, E.; Bhadeshia, H.K.D.H. Influence of silicon on cementite precipitation in steels. Mater. Sci. Technol. 2013, 24, 343-347. [CrossRef]

26. Hofer, C.; Leitner, H.; Winkelhofer, F.; Clemens, H.; Primig, S. Structural characterization of "carbide-free" bainite in a Fe-0.2C-1.5Si-2.5Mn steel. Mater. Charact. 2015, 102, 85-91. [CrossRef]

27. Keehan, E.; Karlsson, L.; Andrén, H.O.; Bhadeshia, H.K.D.H. Influence of carbon, manganese and nickel on microstructure and properties of strong steel weld metals: Part 2-Impact toughness gain resulting from manganese reductions. Sci. Technol. Weld. Join. 2013, 11, 9-18. [CrossRef]

28. Chen, Y.L.; Dong, C.Z.; Cai, Q.W.; Wan, D.C.; Liang, L.I.; Yue, Q.I. Effect of mo and ni on microstructure and mechanical properties of carbide-free bainite ultra-high strength steels. J. Mater. Eng. 2013, 3, 16-21.

29. Chen, J.; Xing, X.; Wang, Y.; Zhou, Y.; Ren, X.; Yang, Y.; Yang, Q. Effects of vanadium addition on microstructure and tribological performance of bainite hardfacing coatings. J. Mater. Eng. Perform. 2015, 24, 1157-1164. [CrossRef] 
30. Kim, K.-S.; Du, L.-X.; Gao, C.-R. Influence of vanadium content on bainitic transformation of a low-carbon boron steel during continuous cooling. Acta Metall. Sin. (Engl. Lett.) 2015, 28, 692-698. [CrossRef]

31. Karmakar, A.; Mukherjee, S.; Kundu, S.; Srivastava, D.; Mitra, R.; Chakrabarti, D. Effect of composition and isothermal holding temperature on the precipitation hardening in vanadium-microalloyed steels. Mater. Charact. 2017, 132, 31-40. [CrossRef]

32. Wang, K.K.; Tan, Z.L.; Gu, K.X.; Gao, B.; Gao, G.H.; Misra, R.D.K.; Bai, B.Z. Effect of deep cryogenic treatment on structure-property relationship in an ultrahigh strength $\mathrm{Mn}-\mathrm{Si}-\mathrm{Cr}$ bainite/martensite multiphase rail steel. Mat. Sci. Eng. A 2017, 684, 559-566. [CrossRef]

33. Kumar, A.; Dutta, A.; Makineni, S.K.; Herbig, M.; Petrov, R.H.; Sietsma, J. In-situ observation of strain partitioning and damage development in continuously cooled carbide-free bainitic steels using micro digital image correlation. Mat. Sci. Eng. A 2019, 757, 107-116. [CrossRef]

34. Mao, X.P.; Huo, X.D.; Sun, X.J.; Chai, Y.Z. Strengthening mechanisms of a new $700 \mathrm{MPa}$ hot rolled Ti-microalloyed steel produced by compact strip production. J. Mater. Process. Technol. 2010, 210, 1660-1666. [CrossRef]

35. Han, S.Y.; Shin, S.Y.; Seo, C.-H.; Lee, H.; Bae, J.-H.; Kim, K.; Lee, S.; Kim, N.J. Effects of Mo, Cr, and V additions on tensile and Charpy impact properties of API X80 pipeline steels. Metall. Mater. Trans. A 2009, 40, 1851-1862. [CrossRef]

36. Donzella, G.; Scepi, M.; Solazzi, L.; Trombini, F. The effect of block braking on the residual stress state of a solid railway wheel. Proc. Inst. Mech. Eng. Part F J. Rail Rapid Transit 1998, 212, 145-158. [CrossRef]

37. Hamada, S.; Sakoda, Y.; Sasaki, D.; Ueda, M.; Noguchi, H. Evaluation of fatigue limit characteristics of lamellar pearlitic steel in consideration of microstructure. J. Soc. Mater. Sci. Jpn. 2011, 60, 790-795. [CrossRef]

38. Zhao, P.; Cheng, C.; Gao, G.; Hui, W.; Misra, R.D.K.; Bai, B.; Weng, Y. The potential significance of microalloying with niobium in governing very high cycle fatigue behavior of bainite/martensite multiphase steels. Mat. Sci. Eng. A 2016, 650, 438-444. [CrossRef]

(C) 2020 by the authors. Licensee MDPI, Basel, Switzerland. This article is an open access article distributed under the terms and conditions of the Creative Commons Attribution (CC BY) license (http://creativecommons.org/licenses/by/4.0/). 